\title{
An Unknown Page FROM THE LIFE OF JAN BOBRZYŃSKI
}

Słowa kluczowe: antygermanizm, Jan Bobrzyński, socjalizm

Keywo ord s: anti-Germanism, Jan Bobrzyński, socialism

\section{ABSTRACT}

The article is an attempt to analyze two works by Jan Bobrzyński written at the end of World War Two and in the early period of Polish People's Republic: Wspótczesne zadania socjalizmu (The Modern Tasks of Socialism) and Die grosse deutsche Lüge (The Great German Lie). The author compares the contents of the two writings with Bobrzyński's views from before WWII. The question is pondered whether Jan Borzyński's post-war choices, such as joining the Polish Socialist Party or fierce antiGermanism, were the result of the evolution of his views, ideological disorientation, or simply opportunism manifested in adjusting his own beliefs to the needs of the moment?

\section{Introduction}

The figure and political ideas of Jan Bobrzyński might seem to have been 1 researched in depth. In 2009, a significant study by Włodzimierz Mich was published, which examined Jan Bobrzyński's views from the time when 
he was the editor of the "Nasza Przyszłość" (Our Future) journal1'. Also, Jacek Bartyzel devoted one of the chapters of his book Konserwatyzm bez kompromisu (Conservatism Without Compromise) to Bobrzyński's political thought ${ }^{2}$. Considerable efforts were made to popularize Bobrzyński's views by Edward Czapiewski, who in 1998 published a selection of his journalistic works ${ }^{3}$, by Tomasz Sikorski and Adam Wątor, who edited Bobrzyński's memoirs ${ }^{4}$. Moreover, references to Jan Bobrzyński's views can be found in works on the political activities of conservatives by Władysław Władyka, Szymon Rudnicki, Michał Jaskólski, Tomasz Sikorski and Bogdan Szlachta, among others.

However, all these publications focus on the years 1925-1939, examining Bobrzyński's views from a political and economic perspective. Meanwhile, Bobrzyński's activities during World War II and in the first years of the postwar Polish People's Republic, when he was an employee of the State Research Institute of Rural Economics in Puławy (PINGW) and later the Chemical Plants in Dwory, have been somewhat sidelined. A search conducted at the State Archives in Lublin revealed a hitherto unknown episode of Jan Bobrzyński's life, namely his Polish Socialist Party membership (PPS) ${ }^{5}$. This fact is not mentioned in Bobrzyński's memoirs by himself or by his wife Maria Bobrzyńska nee Pager ${ }^{6}$.

${ }^{1}$ W. Mich, Publicystyka polityczna "Naszej Przyszłości” 1930-1939 (Political Journalism of "Nasza Przyszłość", 1930-1939), Lublin 2009.

2 J. Bartyzel, Konserwatyzm bez kompromisu. Studium z zachowawczej myśli politycznej $w$ Polsce (Conservatism without Compromise. A Study of Conservative Political Thought in Poland), Torun 2002. Bartyzel dedicated the third chapter of his book: "Ostatni Stańczyk - Jan Bobrzyński" (Jan Bobrzyński: the Last Stańczyk) to Jan Bobrzyński.

${ }^{3}$ E. Czapiewski, Jan Bobrzyński o kwestiach ustrojowych Drugiej Rzeczypospolitej (Jan Bobrzynski on Constitutional Issues of the Second Polish Republic), Warszawa 1998.

${ }^{4}$ J. Bobrzyński, Zwierciadło gasnacego świata. Pamiętnik z ćwierćwiecza na służbie ojczyzny (A Mirror of the Fading World. A Memoir from the Quarter of a Century in the Service of the Homeland), T. Sikorski, A. Wątor (eds.), Kraków 2019.

${ }^{5}$ Jan Bobrzyński remained a grass root member of the Institute PPS branch (ID number 603874), his wife was a delegate to the PPS District Council and served as its secretary. Maria Bobrzyńska was also a member of the PPS District Political Council (State Archives in Lublin, District Committee of the Polish Socialist Party in Puławy, fonds 35/1260, cat. no. 29/2, 29/4, 29/16, 29/17).

${ }^{6}$ J. Bobrzyński, Zwierciadło gasnqcego świata. Pamiętnik z ćwierćwiecza na stużbie (A Mirror of the Fading World. A Memoir from the Quarter of a Century in the Service of 
From that period comes two of Bobrzyński's works reflecting his political views: Wspótczesne zadania socjalizmu (The Modern Tasks of Socialism) ${ }^{7}$, and Die grosse deutsche Lüge (The Great German Lie) written in German in $1945^{8}$. The latter was never published. The 420-page manuscript is available in the Ossoliński National Institute Library in Wrocław.

The study analyzes both mentioned works and compares their contents with Jan Bobrzyński's views from the pre-war period. The question may be posed whether his post-war choices, such as joining the PPS or fierce antiGermanism, resulted from an evolution of views, ideological disorientation, or simply opportunism manifested in matching his own beliefs to the needs of the moment?

To understand Jan Bobrzyński's ideological choices and learn about their circumstances, it is worthwhile to have a closer look at his biography.

Although Jan Bobrzyński wanted to be a politician, he did not manage very well in this role. He was undoubtedly an excellent chemist, a graduate of Polish and German universities, a PhD holder, a distinguished publicist, and an unorthodox conservative. He treated everything with passion and hated half-heartedness and inconsistency. He was alien to cool calculation and cunning in contacts with other people. In politics, on the other hand, he was an uncompromising, irritable individual who must have discouraged people. Jan Bobrzyński tried to find his place in history at all costs, wanting to match his father ${ }^{9}$. He was a man in whom the values of different eras were mixed. As

the Homeland), Ossoliński National Institute Library in Wrocław, manuscript, cat. no. 13531/II; M. Bobrzyńska, Życie zmiennym jest (Life is Fickle), cat. no. Kórnik Library, cat. no. BK 12974/1-2.

7 J. Bobrzyński, Modern Tasks of Socialism - paper delivered during the general meeting of the Institute PPS branch on May 20, 1948, district secretariat - minutes of meetings of PPS district party organizations in Puławy with supplements, State Archives in Lublin, fonds 35/1260, cat. no. 29/11, pp. 108-112.

8 J. Bobrzyński, Die grosse deutsche Lüge (The Great German Lie), Ossoliński National Institute Library, manuscript, cat. no. 14379/II. Bobrzyński completed the manuscript in August 1945.

${ }^{9}$ Jan Bobrzyński tried to live up to his father's expectations, remaining in conflict with him for almost his entire life. The psychiatrist who treated him had no doubt that Jan suffered from the father complex (W. Łazuga, Poznań w życiu ostatniego stańczyka (Poznan in the Life of the Last Stańczyk), [in:] Rzeczy większe i mniejsze (Things Big and Small), Poznań 2002, p. 266). 
Bobrzyński admitted himself, his personality was significantly influenced by his education at German universities. He often expressed extreme opinions and developed several original concepts, for which he was hailed a dreamer, a fantasist, and a doctrinaire ${ }^{10}$.

Jan Bobrzyński's biography from before World War II has been sufficiently discussed in my earlier book Jan Bobrzyński. Portret polityczny (Jan Bobrzyński. A Political Portrait ${ }^{11}$. Thus, in this paper, I focus only on the last thirteen years of his life.

Before the outbreak of World War II, Jan Bobrzyński followed various pathways in his life. First, he worked in the Polish oil industry ${ }^{12}$, then in state administration ${ }^{13}$. He combined his clerical duties with journalist activities. During this time, he published several pamphlets, mainly on economic issues ${ }^{14}$.

Over time, Bobrzyński decided to try his hand in the private sector. In the early 1920s, he founded the Polish Coal Society, a company specializing in the innovative process of coal gasification, which collapsed after a few years, depriving all shareholders of their savings. It was then that Jan Bobrzyński became involved in politics. For several years he served as Secretary-General of the conservative party of the National Right (SPN). He combined his political activities with journalism. His articles were published in such journals as "Polonia", published in Katowice, and "Dziennik Poznañski" (The Poznań

10 Bobrzyński's ideas include various concepts that a sober-minded person may consider unreal or fantastic, but it should be remembered that in politics the line between realism and fantasy is very unstable. Moreover, from today's perspective and with our present knowledge, his views may seem unrealistic but when taking the average opinions of various political circles from interwar Poland such an assessment is no longer clearly justified.

11 S. Paczos, Jan Bobrzyński, portret polityczny (Jan Bobrzyński: A Political Portrait), Poznań 2019.

12 For several years he worked with the oil company "Steaua Roman" as a chemist in Bucarest, Ploiești and Câmpina in Romania.

13 Immediately after World War One Bobrzyński started working in the Polish Ministry of Industry and Trade as a senior clerk.

14 J. Bobrzyński, Na przełomie polskiego przemysłu. Studium ekonomiczne (At the Turn of the Polish Industry. An Economic Study), Warszawa 1919; Monopole w Polsce (Monopolies in Poland), Warszawa 1919; Polski Bank Emisyjny (Emission Bank of Poland), Warszawa 1921; Wielki Czyn. Przyczynek do walki o sanację waluty (The Grand Act. A Contribution to the Struggle for Currency Reform), Warszawa 1923. 
Daily). He also occasionally contributed to "Czas" (The Time) and "Kurier Polski" (The Polish Courier). However, Bobrzyński became most closely associated with the conservative daily "Dzień Polski" (The Polish Day) ${ }^{15}$, of which he was editor-in-chief for a short time.

As I have already mentioned, Bobrzyński was an uncompromising, touchy person who must have disaffected many people. Bobrzyński's father, who knew well his character traits, looked at his son's first steps in politics with fear but was not opposed to his political activities. During his political career, Jan Bobrzyński undertook many initiatives that SPN members did not appreciate. These included his idea of the United Economic Front, the establishment of new branches of the party, and efforts to consolidate the conservatives' place in Józef Piłsudski’s Sanation movement. The antagonisms between Bobrzyński and the party authorities, the conservatives' gradual drawing closer to the Piłsudski's political camp, and the subsequent formation of the Union of Conservative Organizations prompted Bobrzyński to attempt to become more politically independent ${ }^{16}$.

In April 1930, the first issue of the monthly "Nasza Przyszłość" (Our Future) was published with the subheading "Wolna Trybuna Zachowawcza Myśli Państwowej" (Free Tribune of Conservative State Thought). "Nasza Przyszłość" attracted people with conservative views who were supposed to be rivals to the SPN. With time, Bobrzyński organized his activities into the form of the Union of Polish State Thought. From the very beginning, the journal was the apple of his eye. Bobrzyński edited and wrote most of the articles,

15 "Dzień Polski" (The Polish Day) - a conservative press organ published in Warsaw, founded by landowners from Poznań and taken over by the Warsaw conservatives in 1926. From January 1, 1927 it was published as a journal of the Warsaw Stronnictwo Prawicy Narodowej (The Party of the National Right) (SPN).

${ }^{16}$ On February 27, 1933, the Zjednoczenie Zachowawczych Organizacji Politycznych (the Union of Conservative Political Organizations) was founded. Although Bobrzyński was elected to the authorities of this new organization, he did not actually take part in it. In the February issue of "Nasza Przyszłość" (Our Future) an announcement was published that J. Bobrzyński had resigned all his functions in the SPN as well as his deputy member mandate of the Conservative Committee (Editorial, "Nasza Przyszłość" 1933, vol. 28, p. 105). 
also under the penname "Stańczyk". Moreover, Włodzimierz Mich presumes that most texts signed "Editors" were also written by Bobrzyński ${ }^{17}$.

Since the mid-1930s, Jan Bobrzyński was increasingly drawn to counteracting foreign agencies' activity. Furthermore, by promoting anti-Bolshevik ideas in "Nasza Przyszłość", he pointed to Masonic influences as a factor facilitating the USSR to exert political pressure on the politics of France and Czechoslovakia $^{18}$. He also cooperated with the Polish Sanation government drafting propaganda brochures ${ }^{19}$. In 1939, Bobrzyński received a major commission from the Council of Ministers to develop a thorough reorganization of state authorities to reduce the number of ministries, accumulate the relevant state secretariats, and develop the institution of the Chancellery in Poland.

Jan Bobrzyński spent the first weeks of World War II in Lviv, observing the Soviet troops entering the city, and in November 1939, he returned to Warsaw in a cattle wagon. Soon after, he was summoned to the Gestapo headquarters on Szucha Avenue, where Nazi officers familiar with his anti-Bolshevik activities tried to probe him about his views on a war between the Soviet Union and Nazi Germany. To the question "who will win?" he was supposed to answer that the winner would be the Jews ${ }^{20}$. Shortly afterward, Bobrzyńśki was approached by representatives of the Polish Underground State with a death sentence for his alleged cooperation with the Nazi occupiers. He was suspected of taking part in talks with Hermann Göring, which were supposed to lead to the collaboration between Poles and Germans. However, Bobrzyński man-

17 See the description of the journal profile in W. Mich, Publicystyka polityczna "Naszej Przyszłości" 1930-1939 (Political Journalism of "Nasza Przyszłość"), Lublin 2009, pp. 35-44.

18 J. Bobrzyński, Przeciw bolszewizmowi, czy za nim? (Bolshevism: For or Against?) "Nasza Przyszłość" 1936, vol. 47; Wstrzasające odkrycie (Na marginesie bolszewizmu) (A Harrowing Finding (On the Margin of Bolshevism)), "Nasza Przyszłość" 1937, vol. 55; Duch ofensywny jako niezbędna podstawa współczesnej psychiki polskiej (The Offensive Spirit as an Indispensable Foundation of the Modern Polish Psyche), "Nasza Przyszłość" 1939, vol. 68-69.

19 J. Bobrzyński, Bolszewicka prawda. Poświęcone rozwadze Polaków wszystkich sfer i zawodów (The Bolshevik Truth. Dedicated to the Prudence of Poles of All Walks of Life and Professions), Warszawa 1936.

${ }^{20}$ M. Bobrzyńska, Życie zmiennym jest (Life is Fickle), vol. 3, cat. no. 13533, p. 26. 
aged to dissuade the Polish officials from carrying out the sentence by claiming cooperation with people associated with the Underground State ${ }^{21}$.

On his return to Warsaw, Bobrzyński began his political activities. He organized an underground policy program study center in his apartment at 11 Zurawia St, modeled on the activities of the Związek Polskiej Myśli Państwowej (Union of Polish State Thought). At the forefront of his "New Poland" program was a project to build a block of Central European states, solve the issue of national minorities, and raise the level of state industrialization, mainly based on the defense industry ${ }^{22}$.

The aim of study program meetings was also to promote the "supreme Polish national idea". As part of this undertaking, Jan Bobrzyński cooperated with Jerzy Osmołowski, Jan Lutosławski, Stanisław Wańkowicz, Jerzy Ciechomski (President of the Warsaw Union of Landowners), and Kazimierz Marian Morawski. Most likely, Bobrzyński had already worked with Morawski even before the war sharing their shared interest in combating foreign agents and secret societies. There would have been nothing extraordinary in this cooperation, if it had not been for the fact that Morawski was one of the fiercest critics of the Krakow conservatives in the early $1920 \mathrm{~s}^{23}$ and never hid his sympathies toward the nationalist ideology. This seemingly insignificant episode of cooperation with Kazimierz Marian Morawski indicates ideological disorientation in Bobrzyński's life in the late 1930s. Their collaboration can be partly explained by the circumstances of the day, and the defeat of Poland in 1939 sidelined their ideological disputes. Moreover, for almost the entire period of the Second Polish Republic, both of them remained on the margin of mainstream Polish conservatism.

The result of Bobrzyński's study center activities was the drafting of Normy fundamentalne (Fundamental Norms), of which the most important were free-

${ }^{21}$ Ibidem, pp. 31-32. It is quite puzzling that Jan Bobrzyński does not mention this event in his diary. I could not find confirmation of this incident in any other sources. One can only assume that his contacts with many people before the outbreak of the war turned out to be helpful in the mentioned situation.

22 J. Bobrzyński, Zwierciadło..., p. 329.

${ }^{23}$ In 1922 K. M. Morawski published a leaflet: O prawdziwym konserwatyźmie. Pobudka (On True Conservatism. A Wake-up Call), in which he called the "neo-Stańczyks" of Krakow "conservatives of moral void" (K. M. Morawski, O prawdziwym konserwatyzmie. Pobudka, Kraków 1922). 
dom, private property, religion, and family ${ }^{24}$. To implement them, a social and economic organization was to be created, covering the whole society, serving as a model for the other countries of Central Europe.

During the war, like many Poles, Jan Bobrzyńśki lost all his property. $\mathrm{He}$ was forced to take up a variety of activities to provide for his family's livelihoods, such as trying to organize a consignment shop or helping set up a delegation of the Central Welfare Council in Warsaw, to which he was admitted at the request of Adam Romer ${ }^{25}$.

During the Warsaw Uprising of 1944, the tenement house where the Bobrzyńskis had lived since they moved from Vienna was destroyed. All their belongings were buried in the ruins. Moreover, all Bobrzyński's letters, manuscripts and newspaper cut-outs, and memoirs, which he would reconstruct after the war in Puławy, were burnt ${ }^{26}$. The Bobrzyńskis, having nowhere to go, like thousands of destroyed Warsaw residents, set off on a wandering trip for many weeks. During his stay in a camp for fugitives in Ursus, Bobrzyński had an accident and suffered a severe head wound. Eventually, the Bobrzyńskis managed to reach Krakow. They stayed in a homeless shelter run by the Congregation of Albertine Sisters. It was a time of bitterness and disappointment for them. Nowhere, even with their closest family, could they get the slightest support. Thanks to Bishop Adam Sapieha, they found their son Michał, who had been deported to Germany to a forced labor camp during the Warsaw Up-

${ }^{24}$ J. Bobrzyński, Zwierciadło..., pp. 310, 326. The text of the Normy fundamentalne has not survived because after Jan Bobrzyński's death his wife destroyed it in fear of the communist authorities. However, Jacek Bartyzel believes that it did not differ significantly in content from the principles laid out in the recent document of the Union of Polish State Thought titled "Nasz Program" (Our Manifesto) published in "Nasza Przyszłość" in 1939, vol. 71-72, pp. 5-15. Bartyzel believes that the most fundamental norm was freedom (J. Bartyzel, Konserwatyzm bez kompromisu..., p. 175).

${ }^{25}$ The Central Welfare Council (RGO) was a Polish charity operating during both world wars. During World War II Adam Ronikier, with the consent of Nazi GovernorGeneral Hans Frank, resumed its activity. The Council was supported by Archbishop Adam Stefan Sapieha. At that time about 700-900 thousand Poles a year benefited from its assistance. Adam Ronikier. Pamiętniki 1939-1945, ed. M. Rydel, Kraków 2001.

${ }^{26}$ In June 1944 the memoirs were almost ready. The Teslar company declared its intention to publish them and paid Bobrzyński an advance. J. Bobrzyński, Zwierciadło..., p. 359 . 
rising. Unfortunately, shortly after his return to Kraków, Michał Bobrzyński was imprisoned and murdered by the Nazis ${ }^{27}$.

The war and the death of his son changed Jan Bobrzyński profoundly. In the Polish People's Republic, Bobrzyński could not find himself in the new reality. In July 1945, at the request of his second son, Aleksander, he moved to Puławy, where the Bobrzyński family lived at 14 Józef Bem Street. In 1946, Jan started working at the State Research Institute of Rural Economics in Puławy (PINGW), setting up a publishing house and then the Office of Agricultural Propaganda ${ }^{28}$. In addition to regular activities such as preparing various administrative unit reports, the Office provided advice on the radio and the press. Once a week, Jan Bobrzyńśki sent the so-called "advisory dispatches" to Lublin's radio station.

Moreover, in cooperation with the employees of the Institute's departments, he answered letters concerning agriculture sent in by the listeners. As head of the Office, Bobrzyński expanded its press service, publishing articles in various dailies, including "Życie Lubelskie" (The Lublin Life), where several times a week he ran a column Skrzynka informacyjna P.I.N.G.W. (Information Box of the State Research Institute of Rural Economics in Pulawy) ${ }^{29}$. Besides, Jan Bobrzyński was involved in the process of preparing a manual about research institutes. As head of the office, he was in constant contact with journalists and gave many lectures on various agricultural issues and "the Institute's role and scientific knowledge in the new state system" ${ }^{\text {"30 }}$.

Jan Bobrzyński delivered lectures on philosophy at the Folk High School. At that time, he took the initiative to improve the quality of education. He proposed, among other things, to introduce the history of natural sciences as an independent subject of research.

27 M. Bobrzyńska, Życie zmiennym jest, vol. 3, cat. no. 13533, pp. 80-87.

${ }^{28}$ Activity report of the State Research Institute of Rural Economics in Puławy for the second quarter of 1948, the Puławy Branch of the Michał Oczapowski Central Agricultural Library, p. 1.

29 J. Bobrzyński, Skrzynka informacyjna P.I.N.G.W. (Information Box of the State Research Institute of Rural Economics in Puławy), “Życie Lubelskie” 1948, no. 86, 91, 93, 99, 102.

30 Activity report the State Research Institute of Rural Economics in Puławy for the second quarter of 1948, the Puławy Branch of the Michał Oczapowski Central Agricultural Library, pp. 1-2. 
He also actively participated in the ongoing discussion on the future of the Institute. To save the Institute from closure, he went to Warsaw several times and met with the Ministry of Agriculture representatives. It did not work out very well. He only fell afoul of his superiors, who in retaliation decided to close the Institute Office of Agricultural Propaganda on July 1, 1948.

As a result of the reorganization at the State Research Institute and the experienced harassment by members of the Polish Workers' Party, at the end of 1948, Bobrzyński was forced to move to Oświęcim ${ }^{31}$, where he took up a job at the Chemical Plants in Dwory, initially becoming the manager of the production planning department. He and his wife lived in a small apartment at 6/4 Łukaszewicza Street. Shortly before his death, he was transferred to the technical department as an independent research worker ${ }^{32}$. The progressing kidney disease and harsh living conditions hastened the end of his life. Jan Bobrzyński died in a hospital in Krakow on September 3, 1951.

\section{Jan Bobrzyński and Socialism}

In 1947 Jan Bobrzyński and his wife decided to join the Polish Socialist Party (PPS). They explained their decision by the difficult financial situation in which they found themselves in Puławy, the pressure from the Institute's authorities, and the prospect of losing their jobs. While Jan Bobrzyński remained a private member of the Institute PPS branch with the ID number 603874, his wife was a delegate to the PPS District Council, acting as its secretary. Maria Bobrzyńska was also a member of the PPS District Political Council ${ }^{33}$. At one of the party meetings, Bobrzyński argued that his party membership was motivated by the PPS ideology, which the party should zealously nurture, not limiting itself to dealing with immediate matters because, as he put it, a "solid

31 Bobrzyński's wife mentions the harassment by some PINGW employees. The reason for this was to be Bobrzyński's family name, manifestations of his devotion to religion, and a rumor of his intent to run for the future director of the Institute (M. Bobrzyńska, Życie zmiennym jest, part II, Kórnik Library, cat. no. BK 12974/1-2, part IV, p. 36).

32 Letter from the management of the Oświęcim Chemical Plants to Jan Bobrzyński, March 31, 1950. Michał Bobrzyński's private archives.

33 State Archives in Lublin, District Committee of the Polish Socialist Party in Puławy, fonds 35/1260, cat. no. 29/2, 29/4, 29/16, 29/17. 
ideological platform ensures the party's longevity and raison d'être under any circumstances" 34 . He and his wife tried to rationalize their decision, deluding themselves in the assurances of one of the members of the PPS district organization, Marian Zuchmantowicz, that religion is a private matter of conscience, the party does not interfere with it, and there is still a long way for the Polish Socialist Party before any prospective joining the communist Polish Workers' Party ${ }^{35}$.

Jan Bobrzyński's attitude toward socialism is reflected in his paper Modern Tasks of Socialism, delivered during a general meeting of the Institute PPS branch on May 20, 1948. The paper, which hardly flatters the state authorities, apart from individual perspectives, clearly presents Bobrzyński's pre-war views, especially his pro-state and pro-modernization stance. By distinguishing between scientific socialism and systemic socialism, Bobrzyński defined the socialist doctrine as the pursuit of social justice through neighbor's love. At the same time, he emphasized that the same goal and the same principle had been guiding Christianity for centuries. He wrote: "Just as socialism was the concretization of the same goal on the secular path, so was Christianity the concretization of the same goal on the religious and spiritual path. There is no doubt that if Christ lived and acted today - with some reservations - he would take our side and not the side of the capitalist system abuses"36. Bobrzyński stressed in his speech that the conflict between socialism and Christianism should not be seen in theology, because "true socialism" is not concerned with religion. The conflict arose against the background of property relations and old privileges of the clergy. Thus, in its struggle against capitalism, socialism

${ }^{34}$ Report from the meeting of the Institute PPS branch on June 12, 1948, district secretariat - minutes of meetings of PPS district party organizations in Puławy with supplements, State Archives in Lublin, fonds 35/1260, cat. no. 29/11, p. 116.

${ }^{35}$ M. Bobrzyńska, Życie zmiennym jest (Life is Fickle), vol. 4, cat. no. 13533, p. 77; see the minutes of the general meeting of the district PPS party organization at the Puławy Institute, April 27, 1948, minutes of meetings of PPS district party organizations in Puławy with supplements, State Archives in Lublin, fonds 35/1260, cat. no. 29/11, pp. 99-100.

36 J. Bobrzyński, Współczesne zadania socjalizmu (The Modern Tasks of Socialism), a paper delivered during the general meeting of the Institute PPS branch, May 20, 1948, PPS district secretariat - minutes of meetings of PPS district party organizations in Puławy with supplements, State Archives in Lublin, fonds 35/1260, cat. no. 29/11, p. 110. 
entered into conflict with the church representing the big capital. He was optimistic about the future, believing that the ever-faster development of knowledge contributes to both doctrines' convergence. In his view, the Roman Catholic church hierarchs were aware of the importance of labor and social justice problems, as evidenced by the papal encyclicals. Simultaneously, the socialists were increasingly convinced that by regulating the material relations of men and women, happiness and contentment could not be achieved. At the end of his paper, Bobrzyńśki stated: "I have the feeling that we are now living in an extremely momentous historical era, although many of the short-sighted do not yet understand it at all. It is an era in which the basic tenets of socialism begin to coincide with those of Christianism and scientific knowledge. I allow myself to anticipate in the not-too-distant future the moment when these three lines of human aspiration will eventually converge in recognition of one single path of truth. Because there is only one truth" ${ }^{\text {"37 }}$.

Referring to the concept of the Marxist socio-economic system based on a materialistic worldview Bobrzyńśki pointed out that with the state of knowledge at that time, natural materialism was a universally valid philosophical system accepted in almost all branches of science. He believed that "if Marx had written his works today, their main contents and direction would have been the same [...], but the philosophical reasoning would certainly have been different in many respects. Today, the ancient materialistic view in the natural sciences has already come to an end, and has been replaced by a comprehensive energetic worldview based on modern knowledge, which points to conclusions about the origins, construction, and destiny of the natural world" 38 .

These words delivered by a conservative, private property supporter, who had perceived socialist ideas as the greatest threat to Poland a few years earlier, are at least surprising. In Jan Bobrzyński's pre-war journalism, socialism was seen as a transitional stage on the road to Bolshevism ${ }^{39}$. In an article Postęp a reakcja (Progress versus Reaction) from 1927, Bobrzyński accused socialism of doctrinarianism, partisanship, and social radicalism. He emphasized the unsuitability of the socialists' program to the realities of the Polish state

37 Ibidem, p. 112.

38 Ibidem, p. 111.

39 J. Bobrzyński, Postęp a reakcja (Progress versus Reaction), "Dzień Polski” August 5, 1927, no. 179. 
at the time, writing that, "[...] the old doctrines, begotten in Utopian minds a hundred years ago and rehashed in the 20th century, still hamper progress. Although he acknowledged the patriotism of Polish socialists, Bobrzyński saw in their program mainly the threats of abolishing private property, mechanizing the individual, and striving to negate religion and family. He wrote: Everything that a person likes, worships and values, that enlivens their feelings, abilities, creative energy and more noble instincts [...], is to perish and, in its place, is to be forever subjected to social coercion humiliating the individual to a role devoid of all the feelings and to ideals of a working machine, a hopeless drabness of existence, and an enslavement so terrible that no era of old slavery [...] could ever conceive of" 40 .

The remainder of the article is similar in meaning to the content of the paper from 1948. Bobrzyński saw an opportunity in cooperation with the socialists, but he set conditions that were impossible to meet. He appreciated the socialists' concern for the working class's interests but demanded that they abandon slogans aimed at religion, family, and property rights ${ }^{41}$.

Bobrzyński, in his writings about socialism, both before and after the war, stresses the normative aspect of the doctrine, his expectations of it and almost completely ignored the empirical part. In this way, he created his idealistic vision of socialism, which he was ready to accept and had little to do with the reality in which he lived.

\section{Jan Bobrzyński’s Anti-Germanism}

As far as the second article is concerned, it is worth mentioning that Jan Bobrzyński's intellectual development was, to a large extent, fostered in the German culture circle. He spent several years at German universities. He studied in Karlsruhe and at the Graz University of Technology. He knew and read German philosophers and writers, including Immanuel Kant, Johann Gottlieb Fichte, Johann Wolfgang von Goethe, Friedrich Schiller, and Heinrich Heine.

40 Ibidem.

41 J. Bobrzyński, Podział na kasty (Caste Division), "Dzień Polski” June 7, 1929, no. 151. 
In interwar Poland, Jan Bobrzyński's attitude toward Germany largely depended on geopolitical circumstances. Initially, he did not rule out an agreement with the Germans: "There is much that separates us from the Germans, but we also have much in common with them as two Western nations"42. Jan Bobrzyński's articles in "Nasza Przyszłość" clearly indicate the place of Poland in an anti-Bolshevik alliance alongside Germany and Hungary ${ }^{43}$. According to Bobrzyński, Germany, unlike Russia, was a Western civilization country, i.e. it belonged to the same cultural circle as Poland. He, therefore, claimed that the fight against Germany must ultimately end with an accord because Germany represented great values in Europe ${ }^{44}$. However, this argument did not apply to the Nazis with their neo-pagan ideology. He argued that Poland could not be allied with a government fighting God as a Roman Catholic country. Furthermore, Bobrzyński believed that Nazism hurt Polish nationalism and anti-Semitism by promoting hatred and totalitarianism contrary to Christian principles ${ }^{45}$.

With the rise of revisionist tendencies in Germany, Bobrzyński's views changed dramatically. He returned to the rhetoric characteristic of 1930 when he wrote that Poland could not establish peaceful relations with Germany because Germany considered it a seasonal state. He stressed that Germany's expansionist policy was not only driven by a desire for retribution and vengeance but that its anti-Polish policy was also based on the conviction of certain social and state needs. He wrote that Germany was like "[...] a boiler full of steam seeking an easy way out without any resistance. And it seems to the

42 J. Bobrzyński, Na Wschód czy na Zachód (To the East or to the West), [in:], Na drodze walki..., p. 158.

43 J. Bobrzyński, Sojusz... (Anti-Bolshevik Alliance), "Nasza Przyszłość" 1935, vol. 46, pp. 141-154; Walka ze światem Marksa (The Fight against Marx's World), "Nasza Przyszłość" 1936, vol. 47, pp. 1-21. In the 1930s, he was accused of Germanophilia. This charge was raised in articles by Wincenty Rzymowski, published in "Kurier Poranny", Stanisław Stroński in "Kurier Warszawski" and Ksawery Pruszyński in "Czas" (Stańczyk [J. Bobrzyński], Rozprawa z "Czasem" i inna prasq (Debating "Czas"and Other Newspapers), "Nasza Przyszłość” 1936, vol. 48, pp. 29-38). A few years earlier he had been charged with a similar allegation (see J. Bobrzyński, Zachód czy Rosja (The West or Russia), [in:] Na drodze walki..., pp. 159-161).

44 W. Mich, Publicystyka polityczna..., p. 134.

45 J. Bobrzyński, Wspótczesna tragedia Polaka (The Modern Tragedy of Poles), "Nasza Przyszłość" 1938, vol. 66, pp. 20-22. 
Germans that this vent is only possible in the eastern direction" 46 . According to Bobrzyński, it will be tough to establish peaceful relations with Germany because Poland has always stood in the way of achieving these goals. Peace policy may be one of the possible ways of arranging relations but not the only one and not at any cost. The German claims against the Polish territories must be answered with Polish demands because "it has been historically proven that if we do not demand something from others, others will expect more and more from us" 47 .

However, in his memoirs, reconstructed after the war, Bobrzyński wrote that a strict policy had to be pursued toward Germany and that good relations with the German state could only be maintained if Poland showed the Germans its "armored fist". He wrote: "For Germans are brought up in such a way that they only understand and have respect for it, while all courtesies are explained as weaknesses of their neighbor" 48 .

Before 1939, Jan Bobrzyński was certainly not a Germanophile by conviction and sentiment, such as Władysław Studnicki. His more favorable view of Germany did not stem from his admiration for German culture but a simple conviction that Polish political interests coincided with German ones. It is why his work Die grosse deutsche Lüge (The Great German Lie), in which Bobrzyński considered German professors to be the moral perpetrators of the war, came as no surprise. In the introduction, Bobrzyński stated that the condition for defeating Germany once and for all was to beat it militarily and ridicule German culture, which had exerted an impact on almost all nations ${ }^{49}$.

46 J. Bobrzyński, Klin klinem w perspektywie rozprawy z Niemcami (Fighting Fire with Fire in the Perspective of Confrontation with Germany), "Nasza Przyszłość" 1930, vol. 6, p. 86.

47 J. Bobrzyński, Traktat w Locarno a polityka ekspansji (The Locarno Treaties and the Policy of Expansion), [in:] Na drodze walki..., p. 31.

48 J. Bobrzyński, Zwierciadło..., p. 280.

${ }^{49}$ It is noteworthy that Bobrzyński's work fits into the discussion that began in the 1960s about the German guilt for the outbreak of World War Two - i.e., about whether Adolf Hitler, who was a mere "accident" in German history, was responsible for the war, or whether the entire nation, which as a result of its experiences (including top-down unification by force) acquired such attributes as fascination with force, militarism, etc. that in turn led Germany toward the abyss that it had long been heading for. 
Jan Bobrzyński firmly emphasized that breaking the German offensive spirit would not be achieved only by destroying the National Socialist ideology, which was not conceived in Germany by accident. It would not have been possible and could not have developed so rapidly without the sound foundation prepared by German professors, philosophers, and artists responsible for raising the beast. He wrote: "If the bloody teachings of World War Two are not to be lost, the naive, uncritical faith in the power of German culture and the authority of German professors must be exterminated" ${ }^{\text {"0 }}$. He also pointed out that a German general is less dangerous than a German scholar because he is only a contractor and commands his subordinates in barracks, whereas the "peaceful thinker" exerts an educational effect on the entire nation. Hitler and his executioners simply implemented what the German scholars invented and written down in their bulky volumes with German precision ${ }^{51}$. He wrote: "We saw those unaware but faithful Kant and Fichte followers in green uniforms and brown party uniforms who "in the trenches of their thoughts were unreachable", inflamed by the demagogic and senseless Nazi phrases and doctrine, were completely trapped in their spell. And there could be no doubt that when the "good Germans" of all social classes suddenly appeared before the eyes of the whole world as wild, bloodthirsty beasts that seemed to find sadistic pleasure in the anguish of others, this was the educational result of the great German philosophy that gradually expanded its influence on all areas of knowledge, thoughts, and aspirations, and all Germany's acts"52.

Jan Bobrzyński believed that as long as the German way of life manifested by Prussian militarism and Nazism was not suppressed until its destruction, the German people, who are so eager to keep assaulting despite their military disasters, would play a leading role and would continue to be a threat to other countries ${ }^{53}$.

In his opinion, it was not Johann Gottlieb Fichte or Johann Wolfgang von Goethe who best conveyed the essence of German nature, but Heinrich Heine. Like no one else, he had gained insight into the German psyche and described the truth about the German element's ambitions with incredible accuracy.

\footnotetext{
50 J. Bobrzyński, Die grosse..., pp. 5-6.

51 Ibidem, p. 10.

52 Ibidem, p. 26.

53 Ibidem, p. 12.
} 
Bobrzyński wrote that the first duty of any German patriot who seeks to protect his people and homeland from a recurrence of catastrophes to date would be to carefully study and reflect on Heine's On the History of Religion and Philosophy in Germany ${ }^{54}$. Bobrzyński insisted that he had the opportunity to become well acquainted with German culture and emphatically termed the "German essence". He was convinced that this populous, hard-working, orderloving nation, equipped with a unique organizational talent, could do a great deal better and play a leading role in the development of world culture, but to do so, the Germans had to "sheathe the conqueror's sword" and stop lying. For these two horrors have destroyed the best fruits of their labor ${ }^{55}$. According to Bobrzyński, there is only one solution for the German people: if they want to survive and develop, they must free themselves from their past bond. He wrote: "The Germans must understand that their character traits, of which they are particularly proud, and which their writers and politicians praised, are simply the worst - because they have brought disasters to their nation twice in twenty years" ${ }^{6}$. They have to abandon all their "Teutonic" ways of being so that they can better express their positive qualities. A European consciousness will then awaken in the German soul, which has remained hidden despite all odds. "The Germans should recover from this blindness. Then there will be a suitable "living space" for them without wars or wrongs inflicted on other nations" 57 .

Bobrzyński's experiences from World War II undoubtedly influenced his views expressed in Die grosse deutsche Lüge. The atrocities committed by the Third Reich left a lasting trace in Bobrzyński's psyche. Not without significance was his tragedy mentioned earlier: his son Michał was transported to a forced labor camp in Germany during the Warsaw Uprising and later murdered by the $\mathrm{Nazis}^{58}$.

It is also worth adding that the more or less favorable opinions about Germans in Jan Bobrzyński's journalism were in line with the Party of National

${ }^{54}$ Ibidem, p. 19; see Heine H., Z dziejów religii i filozofii w Niemczech (On the History of Religion and Philosophy in Germany), Kraków 1997.

55 Ibidem, p. 13.

56 Ibidem, p. 388.

57 Ibidem, p. 389.

58 M. Bobrzyńska, Życie zmiennym jest (Life is Fickle), vol. 3, cat. no. 13533, pp. 80-87. 
Right (SPN) position. One of the SPN foreign policy's assumptions was to strive for an arrangement with Poland's western neighbor ${ }^{59}$. In the 1930s, Bobrzyński's views were decisively affected by the direction of the Polish government's foreign policy at the time and the resurgence of revisionist tendencies in Germany. After World War II, as it was the case with war survivors, Bobrzyński's attitude toward the Germans was determined mainly by World War II's personal experiences.

\section{SUMMARY}

In Bobrzyński's political thought, the proportions between his attachment to the principles and his adjustment to the reality of his political life at the time varied depending on the issue he dealt with. Without considering these two dimensions, the reader will be noticing inconsistencies and internal contradictions in Jan Bobrzyński's views.

Having analyzed Bobrzyński's attitude toward Germany, it is possible to risk a statement that he was a realist who considered the historical moment and geopolitical context in his concepts. His views evolved to finally take on an extremely anti-German character after World War II.

In Bobrzyński's flattering statements about socialism and his membership in the Polish Socialist Party, the situation is quite different. Until Jan Bobrzyński joined the PPS, it is rather difficult to find any mention of his sympathies for socialist ideology in his journalism. Bobrzyński's ideological volte-face was not a sign of his ideological disorientation. One can suppose that forced by the circumstances of his life, he made a difficult decision to adjust his convictions to the moment's need. However, some reservations should be raised. Jan Bobrzyński's attitude to socialism is somewhat reminiscent of his position on democracy ${ }^{60}$. He partly accepted formal and legal democracy regarding it as a historical necessity. He identified it with a modern constitutional system, but he saw its true meaning in the principle of egalitarianism and, as such, rejected it.

Just as political realism influenced Bobrzyński's attitude to democracy, his life circumstances led him to accept socialism. After founding the communist Polish United Workers' Party (PZPR), Jan Bobrzyński did not join its structures. In the list

${ }^{59}$ E. Czapiewski, Koncepcje polityki zagranicznej konserwatystów polskich w latach 1918-1926 (The Foreign Policy Concepts of Polish Conservatives in 1918-1926), Wrocław 1988, p. 195.

60 S. Paczos, Jan Bobrzyński..., pp. 257-279. 
of members of the PZPR District Committee in Puławy of October 4, 1949, a note was added to his name that he and his wife had left in an unknown direction, even before the forcing out of PPS members who opposed their absorption into the PZPR. In several documents of the PPS District Council of 1948, his wife's name comes with the annotation "Expelled".

\section{BIBLIOGRAPHY}

ARCHIVES

State Archives in Lublin

Fonds 1282 - the District Committee of the Polish United Workers' Party in Puławy (1949-1951).

Fonds 1265 - the District Committee of the Polish Socialist Party in Puławy cat. no. $1-30$.

Fonds 1501 - the Institute of Soil Science and Plant Cultivation in Puławy, cat. no. 404-426.

Michał Bobrzyński’s (Jan Bobrzyński's grandson) private archives, documents and photographs

\section{Kórnik Library}

Bobrzyńska M., Życie zmiennym jest (Life is Fickle), cat no. BK 12974/1-2.

\section{Ossoliński National Institute Library in Wrocław}

Bobrzyńska M., Życie zmiennym jest (Life is Fickle), manuscript, cat. no. vol. I-V, 13553/II.

Bobrzyński J., Zwierciadło "gasnącego świata". Pamiętnik z ćwierćwiecza na stużbie ojczyzny (A Mirror of the "Fading World". A Memoir from the Quarter of a Century in the Service of the Homeland), manuscript, cat. no. 13531/II.

Bobrzyński J., Die grosse deutsche Lüge (The Great German Lie), manuscript, cat. no. 14379/II.

The Puławy Branch of the Michał Oczapowski Central Agricultural Library

Documents of the Agricultural Propaganda Office, 1946-1949. 


\section{ARTICLES AND PAMPHLETS BY JAN BOBRZYŃSKI}

Bobrzyński J., Bolszewicka prawda. Poświęcone rozwadze Polaków wszystkich sfer i zawodów (The Bolshevik Truth. Dedicated to the Prudence of Poles of All Walks of Life and Professions), Warszawa 1936.

Bobrzyński J., Duch ofensywny jako niezbędna podstawa współczesnej psychiki polskiej (The Offensive Spirit as an Indispensable Foundation of the Modern Polish Psyche), "Nasza Przyszłość" 1939, vol. 68-69.

Bobrzyński J., Gruba Berta. Odpór "Naszej Przyszłości” na atakp. S. Strońskiego i niektórych innych prasowców (Big Bertha. The Response of "Nasza Przyszłośc" to the Attack of Mr. S. Stroński and Some Other Journalists), Warszawa 1936.

Bobrzyński J., Klin klinem $w$ perspektywie rozprawy z Niemcami (Fighting Fire with Fire in the Perspective of Confrontation with Germany), "Nasza Przyszłość" 1930, vol. 6.

Bobrzyński J., Monopole w Polsce (Monopolies in Poland), Warszawa 1919.

Bobrzyński J., Na Wschód czy na Zachód (To the East or to the West), [in:] Na drodze walki. $Z$ dziejów odrodzenia myśli konserwatywnej w Polsce (On the Path of Struggle. On the History of the Revival of Conservative Thought in Poland), ed. J. Bobrzyński, Warszawa 1928.

Bobrzyński J., Podział na kasty (Caste Division), “Dzień Polski” 7.06.1929, no. 151.

Bobrzyński J., Polski Bank Emisyjny (Emission Bank of Poland), Warszawa 1921.

Bobrzyński J., Postęp a reakcja (Progress versus Reaction), “Dzień Polski” 5.08.1927, no. 179.

Bobrzyński J., Przeciw bolszewizmowi, czy za nim? (Bolshevism: For or Against?) "Nasza Przyszłość" 1936, vol. 47.

Bobrzyński J., [Stańczyk], Rozprawa z "Czasem" i inna prasq (Disputing "Czas" and Other Newspapers), "Nasza Przyszłość” 1936, vol. 48.

Bobrzyński J., Sojusz antybolszewicki (Anti-Bolshevik Alliance), "Nasza Przyszłość" 1935, vol. 46.

Bobrzyński J., Traktat w Locarno a polityka ekspansji (The Locarno Treaties and the Policy of Expansion), [in:] J. Bobrzyński, Na drodze walki. Z dziejów odrodzenia myśli konserwatywnej w Polsce (On the Path of Struggle. From the History of the Revival of Conservative Thought in Poland), Warszawa 1928.

Bobrzyński J., Walka ze światem Marksa (The Fight against Marx’s World), "Nasza Przyszłość" 1936, vol. 47.

Bobrzyński J., Wielki Czyn. Przyczynek do walki o sanację waluty (The Grand Act. A Contribution to the Struggle for Currency Reform), Warszawa 1923.

Bobrzyński J., Wspótczesna tragedia Polaka (The Modern Tragedy of Poles), "Nasza Przyszłość" 1938, vol. 66.

Bobrzyński J., Wstrzasające odkrycie (Na marginesie bolszewizmu) (A Harrowing Finding (On the Margin of Bolshevism)) “Nasza Przyszłość” 1937, vol. 55. 
Bobrzyński J., The West or Russia, [in:] Na drodze walki. Z dziejów odrodzenia myśli konserwatywnej $w$ Polsce (On the Path of Struggle. From the History of the Revival of Conservative Thought in Poland), ed. J. Bobrzyński, Warszawa 1928.

\section{STUDIES, ARTICLES, REFERENCE PUBLICATIONS}

Bartyzel J., Konserwatyzm bez kompromisu. Studium z zachowawczej myśli politycznej $w$ Polsce (Conservatism without Compromise. A Study of Conservative Political Thought in Poland), Torun 2002.

Bobrzyński J., Zwierciadło gasnqcego świata. Pamiętnik z ćwierćwiecza na służbie ojczyzny (A Mirror of the Fading World. A Memoir from the Quarter of a Century in the Service of the Homeland), eds. T. Sikorski, A. Wątor, Kraków 2019.

Czapiewski E., Jan Bobrzyński o kwestiach ustrojowych Drugiej Rzeczypospolitej (Jan Bobrzyński on Constitutional Issues of the Second Polish Republic), Warszawa 1998.

Czapiewski E., Koncepcje polityki zagranicznej konserwatystów polskich w latach 1918-1926 (The Foreign Policy Concepts of Polish Conservatives in 1918-1926), Wrocław 1988.

Heine H., Z dziejów religii i filozofii w Niemczech (On the History of Religion and Philosophy in Germany), Kraków 1997.

Łazuga W., Poznań w życiu ostatniego stańczyka (Poznan in the Life of the Last Stańczyk), [in:] Rzeczy większe i mniejsze (Things Big and Small), Poznań 2002.

Mich W., Publicystyka polityczna "Naszej Przyszłości" 1930-1939 (Political Journalism of "Nasza Przyszłość", 1930-1939), Lublin 2009.

Morawski K. M., O prawdziwym konserwatyzmie. Pobudka (On True Conservatism. A Wake-Up (all), Kraków 1922

Paczos S., Jan Bobrzyński, portret polityczny (Jan Bobrzyński. A Political Portrait), Poznań 2018.

Rydel M. (ed.), Adam Ronikier. Pamiętniki 1939-1945 (Adam Roniker. Memoirs, 1939-45), Kraków 2001. 